\title{
Large-scale shifts in phytoplankton groups in the Equatorial Pacific during ENSO cycles
}

\author{
I. Masotti ${ }^{1}$, C. Moulin ${ }^{1}$, S. Alvain ${ }^{2}$, L. Bopp ${ }^{1}$, A. Tagliabue ${ }^{1}$, and D. Antoine ${ }^{3}$ \\ ${ }^{1}$ Laboratoire des Sciences du Climat et de l'Environnement, IPSL-CEA-CNRS-UVSQ CEA/Saclay, UMR 8212, \\ Orme des Merisiers, Bat 712, 91191 Gif sur Yvette, France \\ ${ }^{2}$ Univ. Lille Nord de France, ULCO-LOG, CNRS, UMR 8187, 62930 Wimereux, France \\ ${ }^{3}$ Laboratoire d'Océanographie de Villefranche, LOV, CNRS-UPMC Univ. Paris 06, UMR 7093, Villefranche-sur-Mer, France
}

Received: 23 March 2010 - Published in Biogeosciences Discuss.: 8 April 2010

Revised: 18 November 2010 - Accepted: 25 February 2011 - Published: 4 March 2011

\begin{abstract}
The El Niño Southern Oscillation (ENSO) drives important changes in the marine productivity of the Equatorial Pacific, in particular during major El Niño/La Niña transitions. Changes in environmental conditions associated with these climatic events also likely impact phytoplankton composition. In this work, the distribution of four major phytoplankton groups (nanoeucaryotes, Prochlorococcus, Synechococcus, and diatoms) was examined between 1996 and 2007 by applying the PHYSAT algorithm to the ocean color data archive from the Ocean Color and Temperature Sensor (OCTS) and Sea-viewing Wide Field-of-view Sensor (SeaWiFS). Coincident with the decrease in chlorophyll concentrations, a large-scale shift in the phytoplankton composition of the Equatorial Pacific, that was characterized by a decrease in Synechococcus and an increase in nanoeucaryote dominance, was observed during the early stages of both the strong El Niño of 1997 and the moderate El Niño of 2006. A significant increase in diatoms dominance was observed in the Equatorial Pacific during the $1998 \mathrm{La}$ Niña and was associated with elevated marine productivity. An analysis of the environmental variables using a coupled physical-biogeochemical model (NEMO-PISCES) suggests that the Synechococcus dominance decrease during the two El Niño events was associated with an abrupt decline in nutrient availability $\left(-0.9\right.$ to $-2.5 \mu \mathrm{MNO}_{3}$ month $^{-1}$ ). Alternatively, increased nutrient availability $\left(3 \mu \mathrm{MNO}_{3}\right.$ month $\left.^{-1}\right)$ during the 1998 La Niña resulted in Equatorial Pacific dominance diatom increase. Despite these phytoplankton community shifts, the mean composition is restored after a few months, which suggests resilience in community structure.
\end{abstract}

Correspondence to: I. Masotti

(imasotti@1sce.ipsl.fr)

\section{Introduction}

Productivity in the global ocean is important in governing the oceanic carbon cycle and thus exerts a significant control on the climate of the Earth. Any climate change over coming decades could affect primary productivity (PP) through modifications to the environmental conditions of the surface ocean, such as nutrient supply, stratification and acidification. Recent models that aim to forecast future climate include a representation of the ocean carbon cycle and hence also marine productivity. They all predict a global decrease in PP towards the end of the 21st century (Bopp et al., 2001; Steinacher et al., 2010). Monitoring ocean productivity at the global scale is essential to evaluate such predictions and is only possible at basin scales and greater using ocean color satellite data, which have been routinely available since the end of the 1990's, in particular from the OCTS (1996-1997), SeaWiFS (1997-) and MODIS (2002-) sensors. Such data allow for the quantification of chlorophyll- $a$ concentrations (Chl- $a$ ) in ocean surface waters, which is necessary to estimate PP (Behrenfeld and Falkowski, 1997). In the Equatorial Pacific (EQPAC) region, observed changes in productivity have been associated with regional climatic events, such as the El Niño Southern Oscillation (ENSO) (e.g., Chavez et al., 1999; Gregg and Conkright, 2002), one of the major natural climatic events that occurs regularly but with a variable intensity. Behrenfeld et al. (2006) estimated that the major El Niño and La Niña (ENLN) transitions between 1997 and 1999 resulted in a $262 \mathrm{Tg}$ increase in global PP. Changes in PP during ENLN are essentially associated with the changes in the supply of the nutrients necessary for phytoplankton photosynthesis (e.g., nitrogen, phosphorous, iron).

Published by Copernicus Publications on behalf of the European Geosciences Union. 

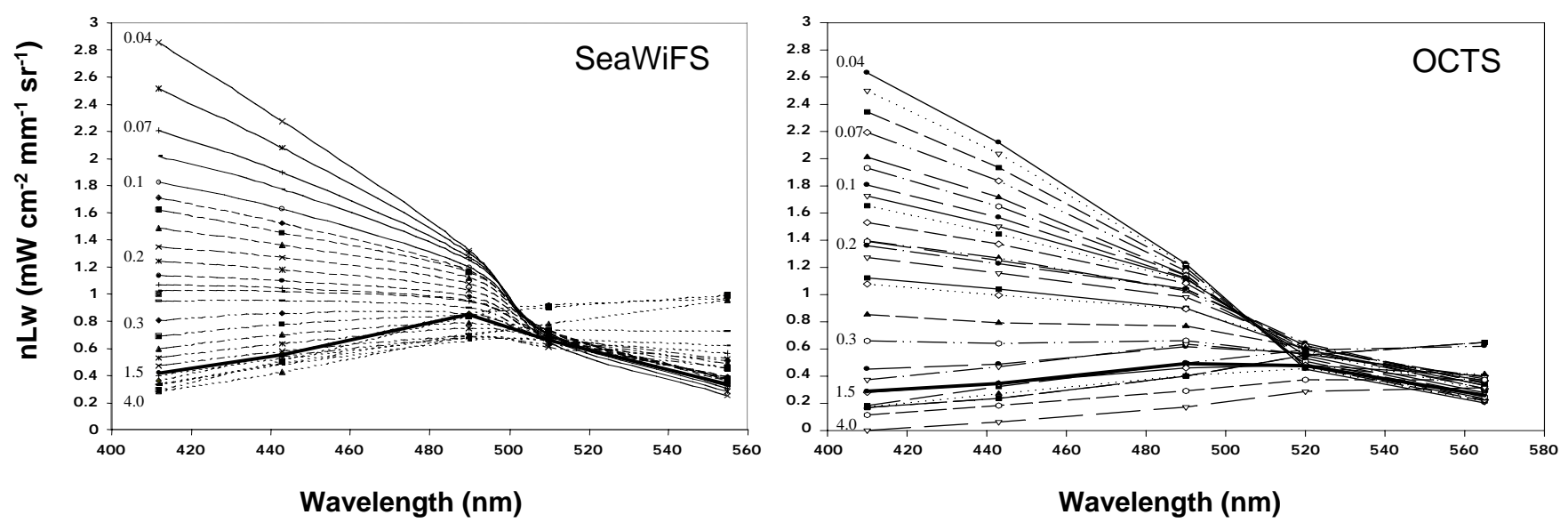

Fig. 1. A comparison between the SeaWiFS (left) and OCTS (right) reference model ( $\mathrm{LLw}_{\mathrm{ref}}$ ) of the normalized water-leaving radiance $(\mathrm{nLw})$ as a function of wavelength for various chlorophyll- $a$ concentrations $(\mathrm{Chl}-a)$.

Photosynthetic performances and nutrient demands differ between different phytoplankton groups. For example, diatoms are twice as efficient as typical equatorial picoplankton (e.g., Prochlorococcus and Synechococcus) in carbon fixation, despite having a higher nutrient demand (e.g., Veldhuis et al., 2005; Sarthou et al., 2005). In this context, it is unsurprising that the composition of the phytoplankton community also changes during ENLN transitions (Chavez et al., 1999). Consequently it can be anticipated that observed changes in PP during ENLN depend on the specific phytoplankton group composition. The characterization of the specific phytoplankton group composition is possible from space using the PHYSAT algorithm (Alvain et al., 2005). The PHYSAT algorithm detects the Phytoplankton Functional Type (PFT) when they are dominant and has already been used to show a major diatom bloom during La Niña 1998 in the eastern EQPAC region using SeaWiFS data (Alvain et al., 2008).

Our goal here is to use satellite archives to study the variability in the distribution of PFTs during the ENSO cycle in the EQPAC over the last decade. In order to cover the totality of the 1997 El Niño event that started prior to the SeaWiFS era, we have used OCTS data. We have adapted the PHYSAT algorithm to also process OCTS data in order to be able to analyze phytoplankton changes during the particularly strong 1997-1998 ENLN events. The PHYSAT algorithm is used here to detect the distribution of four PFTs (i.e., Prochloroccocus, Synechococcus, nanoeucaryotes and diatoms) in the EQPAC region between November 1996 and December 2007. In addition, we use simulated nutrients fields from the NEMO-PISCES model to better understand the link between the phytoplankton changes detected by PHYSAT and variability in environmental conditions.

\section{Data and methods}

\subsection{Satellite data processing}

The dataset used in this work combines OCTS data (from November 1996 to June 1997) with SeaWiFS data (from September 1997 to December 2007) to obtain a time series that spans the period November 1996 to December 2007, with a gap between July-August 1997. All Level 3 binned daily products were downloaded from the NASA/GSFC/DAAC ftp site (ftp://oceans.gsfc.nasa.gov). Input data for the PHYSAT algorithm (in brackets for OCTS if different from SeaWiFS) are Chl- $a$, the aerosol optical thickness at $865 \mathrm{~nm}$ and normalized water-leaving radiances $(\mathrm{nLw})$ at $412(410), 443,490,510(520)$ and $555(565) \mathrm{nm}$.

PHYSAT was developed to identify the dominant PFT from SeaWiFS measurements (Alvain et al., 2005, 2008). This classification relies on the difference between the shapes of the measured $\mathrm{nLw}$ spectrum between 412 and $555 \mathrm{~nm}$ and of a reference spectrum $\mathrm{nLw}_{\text {ref }}$ that depends only on Chl- $a$, expressed as the specific water-leaving radiance, $\mathrm{nLw}^{*}$ :

$\mathrm{nLw}^{*}(\lambda)=\mathrm{nLw}(\lambda) / \mathrm{nLw}_{\mathrm{ref}}(\lambda, \mathrm{Chl}-a)$

The analysis of coincident $\mathrm{nLw}^{*}$ spectra and in situ pigment inventories performed by Alvain et al. (2005) have shown that PFTs (i.e., Prochloroccocus, Synechococcus, nanoeucaryotes and diatoms) can be individually identified (cf. Fig. 2 in Alvain et al., 2008). Until now, this algorithm has only been applied to SeaWiFS data and its adaptation to OCTS data has to be tested and evaluated carefully before further analysis of our dataset.

In addition to the small changes in spectral bands, several other differences related to the atmospheric correction and bio-optical algorithms used in the standard processing of OCTS data required building a specific model of $\mathrm{nLw}_{\text {ref }}$ (see Eq. 1) for this sensor, using the approach described in Alvain 


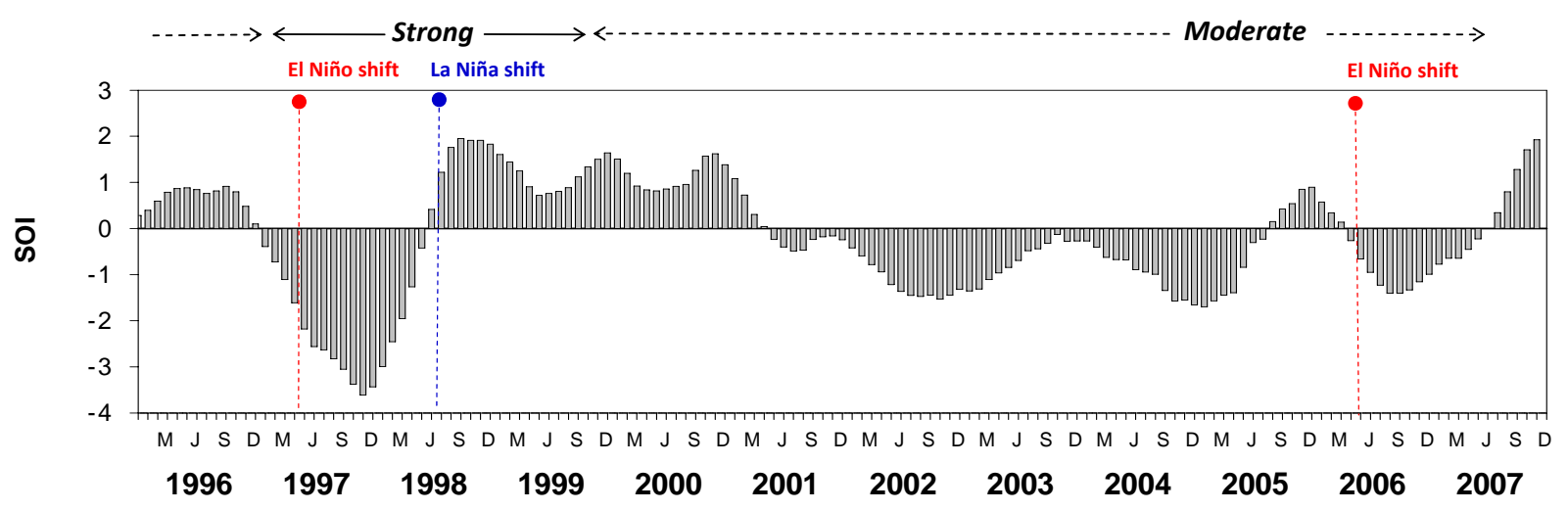

Fig. 2. The Southern Oscillation Index (SOI) that illustrates the main El Niño and La Niña events over 1996-2007 period. El Niño and La Niña periods correspond to negative and positive SOI values, respectively. During this period, strong and moderate El Niño and La Niña periods are denoted by continuous or dashed arrows, respectively. The times when we observe significant shifts in PFT dominance are denoted by vertical dashed lines (cf. Fig. 5e and g).

et al. (2005). Figure 1 shows that both reference models are quite similar at all wavelengths except for high Chl- $a$ values $\left(>1.5 \mathrm{mg} \mathrm{m}^{-3}\right.$, see second left axis, values from 0.04 to $\left.4.0 \mathrm{mg} \mathrm{m}^{-3}\right)$. It is difficult to give an explanation for this latter discrepancy due to the differences listed above. Since these values of chlorophyll $\left(>1.5 \mathrm{mg} \mathrm{m}^{-3}\right)$ do not occur in the EQPAC region (except for a very small area, right at the coast), this issue should not impact our results. It is important to note that this change in $\mathrm{nLw}_{\text {ref }}$ model is the only adaptation of PHYSAT that was made to process OCTS data and that the spectral criteria on $\mathrm{nLw}^{*}$ defined in Alvain et al. (2008) to identify the various PFT were not modified. Further evaluation of the PHYSAT results when applied to OCTS is presented in Sect. 3.1. We note that the PHYSAT method can not provide PFT abundance, only the PFT that is dominant at each particular pixel and at each point in time.

\subsection{Environmental variables}

We used the Southern Oscillation Index (SOI) and the sea surface temperature (SST) satellite product computed from AVHRR data (http://www.cdc.noaa.gov/data/gridded/ data.noaa.oisst.v2.html) to characterize the succession of ENLN events over our period of study. The SOI is illustrated in Fig. 2. In this figure, positive values of SOI indicate La Niña conditions and negative values indicate El Niño conditions over 1996-2007 period. Vertical dashed lines correspond to the onsets of El Niño (red) and La Niña (blue) periods associated to the main PFT shifts. A detailed analysis regarding the relationship between the SOI values, SST and PFT variability is presented in Sect. 4.

To better characterize the variability in environmental conditions (in particular nutrient concentrations), we have employed ocean model simulations performed with the Pelagic Interactions Scheme for Carbon and Ecosystem Studies (PISCES). PISCES is a biogeochemical model (Aumont and
Bopp, 2006), which simulates marine biological production and describes the cycles of carbon and the main nutrients (phosphate, nitrate, ammonium, iron and silicate). Two phytoplankton species (nanophytoplankton and diatoms) and two zooplankton species (mesozooplancton and microzooplancton), as well as two detrital size classes are also represented. PISCES is embedded within the global general ocean circulation model NEMO (Madec, 2008). Here we used a global configuration of NEMO-PISCES with a horizontal resolution of $2^{\circ} \times 0.5-2^{\circ}$ and 31 vertical levels. The surface forcing for the historical period are NCEP-1 (Kalnay et al., 1996) fluxes, with surface heat fluxes calculated using bulk formulae. We initialized NEMO-PISCES with observationally-based climatologies, with spin-up of $150 \mathrm{yr}$ followed by an experimental run for $50 \mathrm{yr}$ from 1948 to 2007 using NCEP-1 forcing. Here we extract selected environmental variables (for example temperature, $T^{\circ}$, nitrate, $\mathrm{NO}_{3}$, and phosphate, $\mathrm{PO}_{4}$ ) over the period 1996-2007. We use the model output to explain possible environmental processes that might explain the PFT variability observed by PHYSAT. Ideally, we would be able to compare the PFT distributions from PHYSAT (i.e., Prochloroccocus, Synechococcus, nanoeucaryotes and diatoms) to those predicted by the model. However, such global models typically do not include such a diversity of PFTs, particularly for the smaller phytoplankton classes. The NEMO-PISCES model includes a generic separation between large, silicifying diatoms and smaller, nonsilicifying nanophytoplankton. Accordingly, any shifts between smaller PFTs (synechococcus, prochloorococcus and nanoeucaryotes) cannot be compared as they would all be present in the "nanophytoplankton" group in the model. On the other hand, a comparison of shifts in diatom dominance from NEMO-PISCES and PHYSAT during La Niña periods was recently performed (Gorgues et al., 2010). In the context of our study, we used NEMO-PISCES to examine likely spatio-temporal changes in the physio-chemical properties of 
the region that cannot be assessed using PHYSAT. While only $\mathrm{NO}_{3}$ changes are presented in this study (see results presented in Sect. 4), we did in fact examine a suite of environmental parameters from NEMO-PISCES, such as $\mathrm{PO}_{4}$, $\mathrm{Fe}$, mixed layer depth and euphotic depth. Our preliminary analysis showed that nutrients exhibited more significant changes over periods of interest. For example during the strong 1997-1998 El Niño condition $\mathrm{Fe}$ and $\mathrm{NO}_{3}$ concentrations decreased by a factor of 1.6 and 2.4 respectively (cf. Fig. S1) compared to a $\sim 10 \%$ decrease/increase in the mixed layer or euphotic depth. Our eventual focus on $\mathrm{NO}_{3}$ is also supported by the fact that (i) regional-mean $\mathrm{PO}_{4}$ concentrations show almost similar inter-annual variations than $\mathrm{NO}_{3}$ in the $180^{\circ} \mathrm{W}-80^{\circ} \mathrm{W}, 10^{\circ} \mathrm{N}-10^{\circ} \mathrm{S}$ region, but with a much smaller relative amplitude $\left( \pm 20 \%\right.$ for $\mathrm{PO}_{4}$ concentrations vs. $\pm 100 \%$ for $\mathrm{NO}_{3}$ concentrations) (ii) mean $\mathrm{Fe}$ concentrations during early state of the El Niño condition show a decrease simultaneous to $\mathrm{NO}_{3}$ and $\mathrm{PO}_{4}$ in the $180^{\circ} \mathrm{W}-80^{\circ} \mathrm{W}, 10^{\circ} \mathrm{N}-10^{\circ} \mathrm{S}$ region, and (iii) although regional $\mathrm{NO}_{3} / \mathrm{Fe}$ present decoupling episodes at inter-annual scales in the $180^{\circ} \mathrm{W}-80^{\circ} \mathrm{W}, 10^{\circ} \mathrm{N}-10^{\circ} \mathrm{S}$ region, $\mathrm{NO}_{3} / \mathrm{Fe}$ show almost similar inter-annual variations in the core of the PFT variability region $\left(140^{\circ} \mathrm{W}-100^{\circ} \mathrm{W}, 10^{\circ} \mathrm{N}-10^{\circ} \mathrm{S}\right.$, see results presented in Sect. 3). Moreover, Fig. S2 shows the $\mathrm{NO}_{3}$, $\mathrm{PO}_{4}$ and $\mathrm{Fe}$ anomaly in the $140^{\circ} \mathrm{W}-100^{\circ} \mathrm{W}, 10^{\circ} \mathrm{N}-10^{\circ} \mathrm{S}$ region. As can be seen, $\mathrm{NO}_{3}, \mathrm{PO}_{4}$ and $\mathrm{Fe}$ show almost similar inter-annual variation, except during mature El Niño conditions (September 1997 to March 1998) when a decoupling between $\mathrm{Fe}$ and $\mathrm{NO}_{3}$ seems to appear. This agrees with the $\mathrm{NO}_{3} / \mathrm{Fe}$ decoupling shown to occur at the decadal time-scale and in the eastern part of the EQPAC region $\left(150^{\circ} \mathrm{W}-90^{\circ} \mathrm{W}\right.$, $2^{\circ} \mathrm{N}-2^{\circ} \mathrm{S}$ ) (Rodgers et al., 2008). In the $180^{\circ} \mathrm{W}-80^{\circ} \mathrm{W}$, $10^{\circ} \mathrm{N}-10^{\circ} \mathrm{S}$ region it is clearly $\mathrm{NO}_{3}$ that controls/limits productivity in NEMO-PISCES model and we therefore focus on the $180^{\circ} \mathrm{W}-80^{\circ} \mathrm{W}, 10^{\circ} \mathrm{N}-10^{\circ} \mathrm{S}$ region where $\mathrm{NO}_{3}$ appears to be a more representative nutrient to explain any PFT variability.

\section{Results}

\subsection{Comparison of OCTS and SeaWiFS global PFT distributions}

Using both OCTS and SeaWiFS data allows a 12-yr (19962007) time series of the dominant PFT distributions from the PHYSAT algorithm. We analyze this data set to monitor the impacts of the ENSO cycle on the distribution of PFTs, including strong and moderate periods of El Niño and La Niña events as suggested by the Southern Oscillation Index (SOI). Figure 2 shows the SOI values over 1996-2007 period, where positive SOI values indicate La Niña conditions and negative values indicate El Niño conditions. In general during this period, we can say that SOI values less than -2.0 correspond to the very strong El Niño of 1997-1998 and SOI val- ues between -1.0 and -2.0 correspond to moderate El Niño conditions during 2002-2003, 2004-2005 and 2006 (Fig. 2). Strong La Niña conditions are characterized by SOI values up to 1.5 (e.g., 1998) and moderate conditions with values around 1.0 (e.g., 1996). The 8 months of OCTS data are key to evaluating the dominant PFT distribution from PHYSAT during the early stage of the strong El Niño 1997. Unfortunately, the total lack of any ocean color data between July and September 1997 precludes an observation of ocean productivity and PFT distributions during the buildup of the most intense El Niño of the last two decades.

Figure 3 shows the comparison between the global distribution of the dominant PFTs (i.e., Prochlorococcus, Synechococcus, nanoeucaryotes and diatoms) obtained with OCTS (November 1996 to June 1997) and with SeaWiFS for each month of 1999 in order to examine the general peformance of PHYSAT with the two sensors. For each pixel, PFT dominance is defined as the PFT with the largest relative frequency of identification using PHYSAT. The most obvious difference between the two datasets in Fig. 3 is the greatly reduced number of pixels available in the OCTS monthly product, relative to SeaWiFS. Therefore, before commencing a more detailed analysis of these two datasets, it is necessary to make sure that the OCTS PFT distributions are comparable with that of SeaWiFS and that the reduced coverage is not due to a problem with the adaptation of PHYSAT to OCTS data.

OCTS has a narrower swath than SeaWiFS and no tilting capability, with both acting to reduce the spatial coverage of its Level-3 daily binned product. The global monthly coverage of OCTS (1996-1997) is around 40 $\pm 6 \%$ of the available Chl- $a$ pixels from SeaWiFS (1999) global coverage i.e. the spatial coverage for OCTS is reduced by 2.5 times. Similarly, there are 2.7 times less pixels available (or $36 \pm 11 \%$ ) for PHYSAT identification using OCTS (relative to SeaWiFS). These results suggest that the changes made to PHYSAT in order to analyze OCTS data do not result in more or less unidentified pixels, which would have suggested an inconsistency between the two PHYSAT processing algorithms.

Even if OCTS data are scarcer than SeaWiFS data, particularly at high latitudes, the geographical distribution of PFTs retrieved during the first six months (November 1996 to April 1997) is very similar to that of SeaWiFS (Fig. 3). In both datasets, diatoms are dominant in the same regions of the Southern Ocean (between $40^{\circ} \mathrm{S}$ and $50^{\circ} \mathrm{S}$ ) during the austral spring-summer period, whereas intertropical regions $\left(20^{\circ} \mathrm{N}-20^{\circ} \mathrm{S}\right)$ are dominated by Prochlorococcus and Synechococcus and subtropical regions $\left(20^{\circ} \mathrm{N}-40^{\circ} \mathrm{N}\right)$ by nanoeucaryotes. However, the PFT distributions in May and June 1997 are markedly different to those of SeaWiFS (Fig. 3). During these two months, Prochlorococcus and Synechococcus are replaced by nanoeucaryotes in the intertropical region $\left(20^{\circ} \mathrm{N}-20^{\circ} \mathrm{S}\right)$ and more specifically in the Equatorial Pacific (EQPAC) region, which is a phenomenon that is not observed with SeaWiFS neither for 1999, nor the climatology 


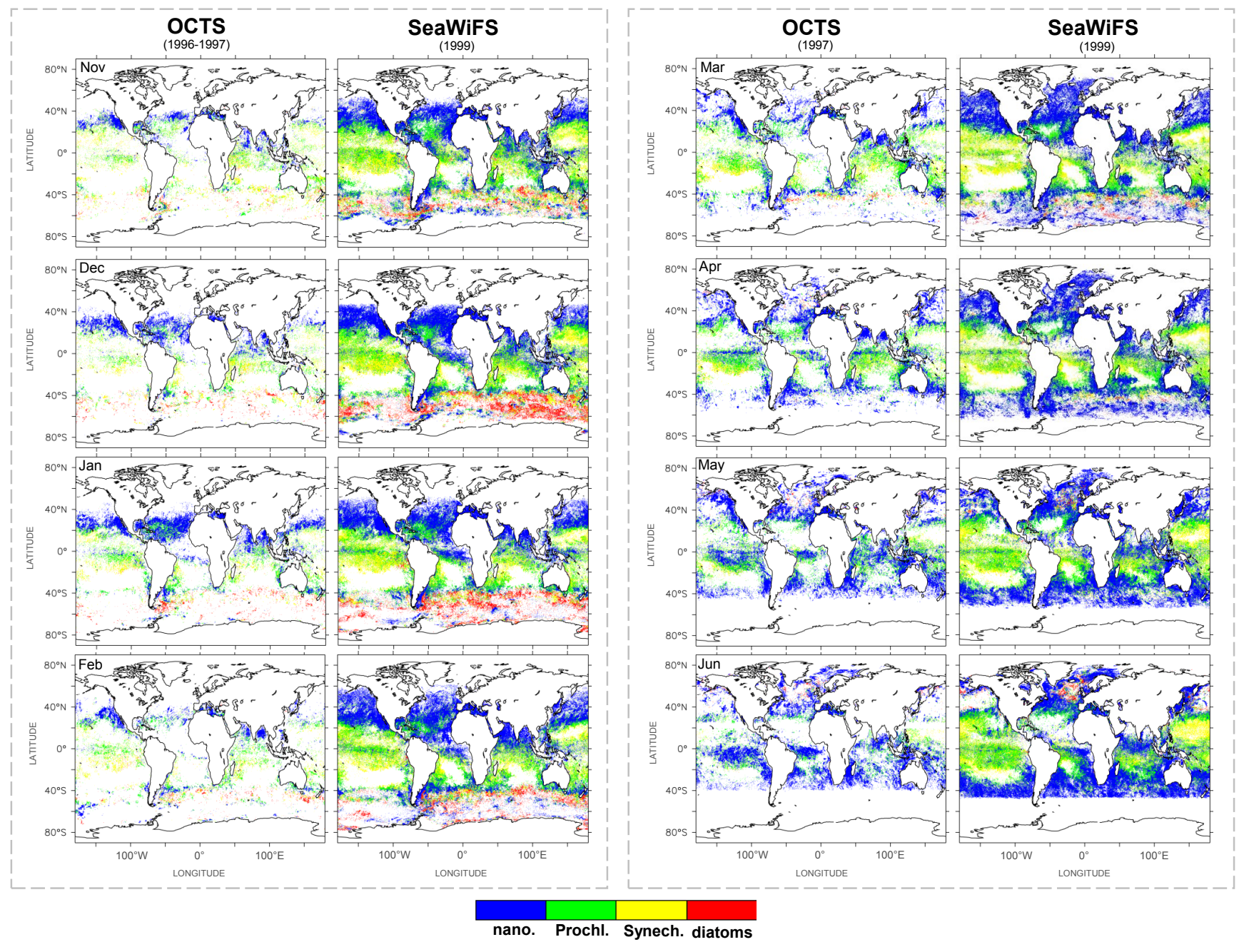

Fig. 3. A comparison between the global distribution each month of the dominant PFT obtained during the early stage of the strong El Niño (1996-1997, OCTS era) and during the La Niña conditions (1999, SeaWiFS era). Phytoplankton group dominance is defined as the group with the largest relative frequency identified by PHYSAT.

of Alvain et al. (2008). On the contrary, the spring diatom bloom in the north Atlantic is similar for both years, which again suggests that PFT dominance shifts in tropical regions is not due to a failure of the PHYSAT algorithm when applied to OCTS.

In Fig. 4, we show the relative global area covered by each dominant PFT group, i.e., Prochlorococcus, Synechococcus, nanoeucaryotes and diatoms each month for both OCTS and SeaWiFS (for 1999, because this year seems representative of the SeaWiFS PFT climatology, as shown in Fig. S3). In Fig. S3 we show a comparison between global area covered (in percentage) by each dominant PFT obtained from SeaWiFs in 1999 and SeaWiFS climatology (between 1997-2007). The percentage of area covered was calculated at the global scale from the number of pixels of a given PFT divided by the total number of pixels classified by PHYSAT. As illustrated in Fig. 4, there are very few differences between OCTS and SeaWiFS in the relative contributions of each PFT dur- ing the first six months (November to April). During this period, similar mean values are observed for nanoeucaryotes $(44 \pm 9 \% / 47 \pm 7 \%)$, Prochlorococcus $(29 \pm 4 \% / 26 \pm 2 \%)$, Synechococcus $(23 \pm 8 \% / 22 \pm 3 \%)$ and diatoms $(4 \pm 2 \% / 6 \pm$ $4 \%$ ), for OCTS and SeaWiFS, respectively. The main differences during these six months occur for the Synechococcus and nanoeucaryote PFTs in January and April. In January 1997, there is a decrease of about $8 \%$ in the Synechococcus contribution which coincides with a similar increase in nanoeucaryotes. A similar 10\% decrease of Synechococcus is also observed in Fig. 4 for April 1997 and is associated with an increase in nanoeucaryotes $(\sim 7 \%)$ and Prochlorococcus $(\sim 3 \%)$. In spite of these small differences, these results suggest that the adaptation of the PHYSAT algorithm was successful and that the reduced number of pixels available from OCTS does not prevent us from using the PFT distributions obtained with OCTS, since they are comparable with those of SeaWiFS. 


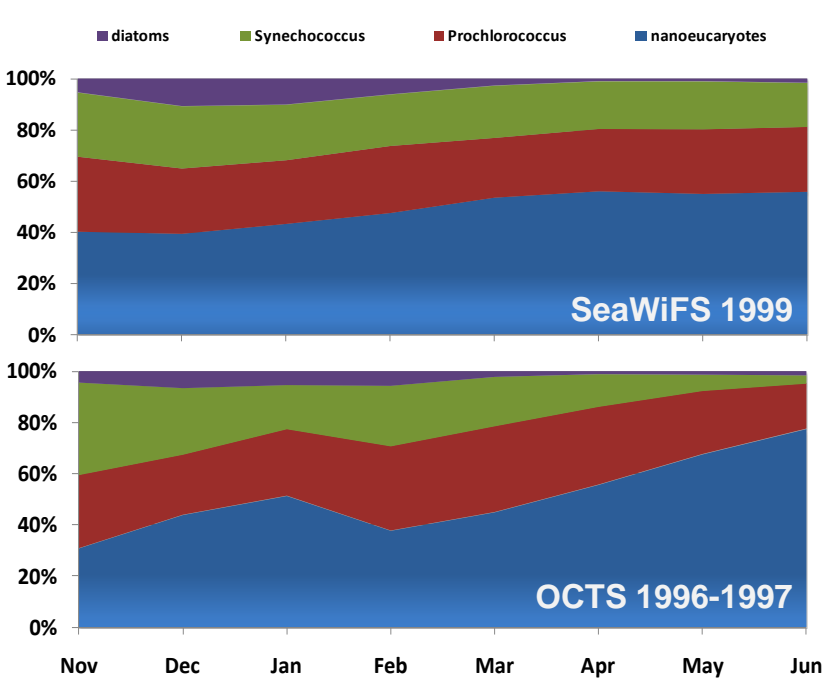

Fig. 4. The monthly areal coverage (in percentage) by each PFT (i.e., Prochlorococcus, Synechococcus, nanoeucaryotes and diatoms) obtained from OCTS (1996-1997, bottom panel) and SeaWiFS (1999, top panel). This was calculated from the data presented in Fig. 3.

Figure 4 also shows significant differences in the distribution of the dominant PFT for both sensors over the last two months (May and June) of the 8-month period. Specifically, an increase of $28 \%$ in the nanoeucaryote contribution, which is associated with a coincident decrease in the Synechococcus $(17 \%)$, Prochlorococcus (8\%), and diatoms (3\%) contributions in May-June 1997, compared with the mean values observed for these PFTs during the first six months. SeaWiFS data for the same months of 1999 do not show anything comparable to these changes. This result is quite intriguing given the consistency of the two datasets for the first six months. No technical problems which could explain these differences in PHYSAT results were reported for OCTS.

\subsection{PFT dominance shifts in the Equatorial Pacific and El Niño/La Niña events}

It is possible that environmental changes associated with the onset of the strong El Niño in summer 1997 are at the origin of this shift in phytoplankton community structure towards nanoeucaryote dominance (at the expense of Synechococcus) in the EQPAC. In order to examine whether similar shifts have occurred over the 1996-2007 period in this region, we produced time series of the PFT dominance anomaly for both equatorial $\left(10^{\circ} \mathrm{N}-10^{\circ} \mathrm{S}\right)$ and tropical $\left(15^{\circ} \mathrm{N}-25^{\circ} \mathrm{N}\right)$ regions of the Pacific and Atlantic Oceans (Fig. 5, the Atlantic Ocean was included to obtain a comparative overview of PFT variability for another tropical region).

The PFT dominance anomaly over the tropical North Pacific (Fig. 5a and c) and North Atlantic (Fig. 5b and d) regions does not show a marked inter-annual variability and remains between -0.3 and 0.3 over the $12 \mathrm{yr}$, even during the onset of the strong El Niño event in May and June 1997. It is however interesting to note the clear seasonal cycle in PFT dominance for the tropical Pacific (Fig. 5a and c). Each year the dominant PFT shifts from Synechococcus in summer to nanoeucaryotes in winter. However, in 1997 nanoeucaryotes persisted into May and June (Fig. 5a and c). Such a seasonal cycle is not observed in the tropical Atlantic (Fig. 5b and d). Diatoms show almost no variability (neither inter-annual nor seasonal), which is not surprising in these nutrient poor oligotrophic regions where diatoms seem not to be a significant PFT (Veldhuis and Kraay, 2004).

The equatorial Atlantic region shows similar behavior to that of the tropical regions, with nanoeucaryote and Synechococcus dominance anomalies remaining in the range -0.3 to 0.3 , with very little inter-annual variability over the 1996-2007 period (Fig. 5f and h). A seasonal cycle with a dominance that alternates between nanoeucaryotes and Synechococcus typifies the equatorial Atlantic, but, contrary to what was observed in the tropical Pacific, there seems to be two peaks for both groups per year (June and December for nanoeucaryotes and September and March for Synechococcus; Fig. 5f). Finally we again find little variability in the diatom dominance anomaly in the equatorial Atlantic, except for two small peaks in November 1996 and September 1997 (Fig. 5h).

In the EQPAC region, the PFT dominance anomalies (Fig. 5e and g) are completely different to those observed in the three other regions. While dominance anomalies are small for all four PFTs and do not show any clear seasonal cycle, there is strong inter-annual variability. At the onset of the 1997 strong El Niño we observe a significant shift from Synechococcus to nanoeucaryotes in spring (Fig. 5e). A similar shift (albeit of lower intensity) is also observed in May-July 2006 during the onset of the moderate (compared to that of 1997) El Niño event (cf. Fig. 2). A significant PFT dominance anomaly is also detected in the EQPAC region during the strong La Niña event of 1998, with this increase in diatom dominance already reported by Alvain et al. (2008) using PHYSAT. There are several other diatom dominance peaks during the study period (1996, 2000, 2003, 2004, 2005-2006, and 2007, Fig. 5g), but they are much more difficult to link with La Niña events, except for those of 1996, 2000 and 2005-2006. Overall, PHYSAT suggests that ENLN events appear to have an influence on the phytoplankton composition in the EQPAC region (Fig. 5e and g), in agreement with in situ measurements (e.g., Chavez et al., 1999).

\subsection{PFT dominance shifts in the Equatorial Pacific and chlorophyll- $a$ concentrations}

To more precisely analyze the PFT dominance shifts during ENLN events, we compared the anomalies of the three most dominant and variable PFTs, i.e., Synechococcus, nanoeucaryotes and diatoms with the Chl- $a$ concentration estimated 


\section{Pacific}

\section{Atlantic}

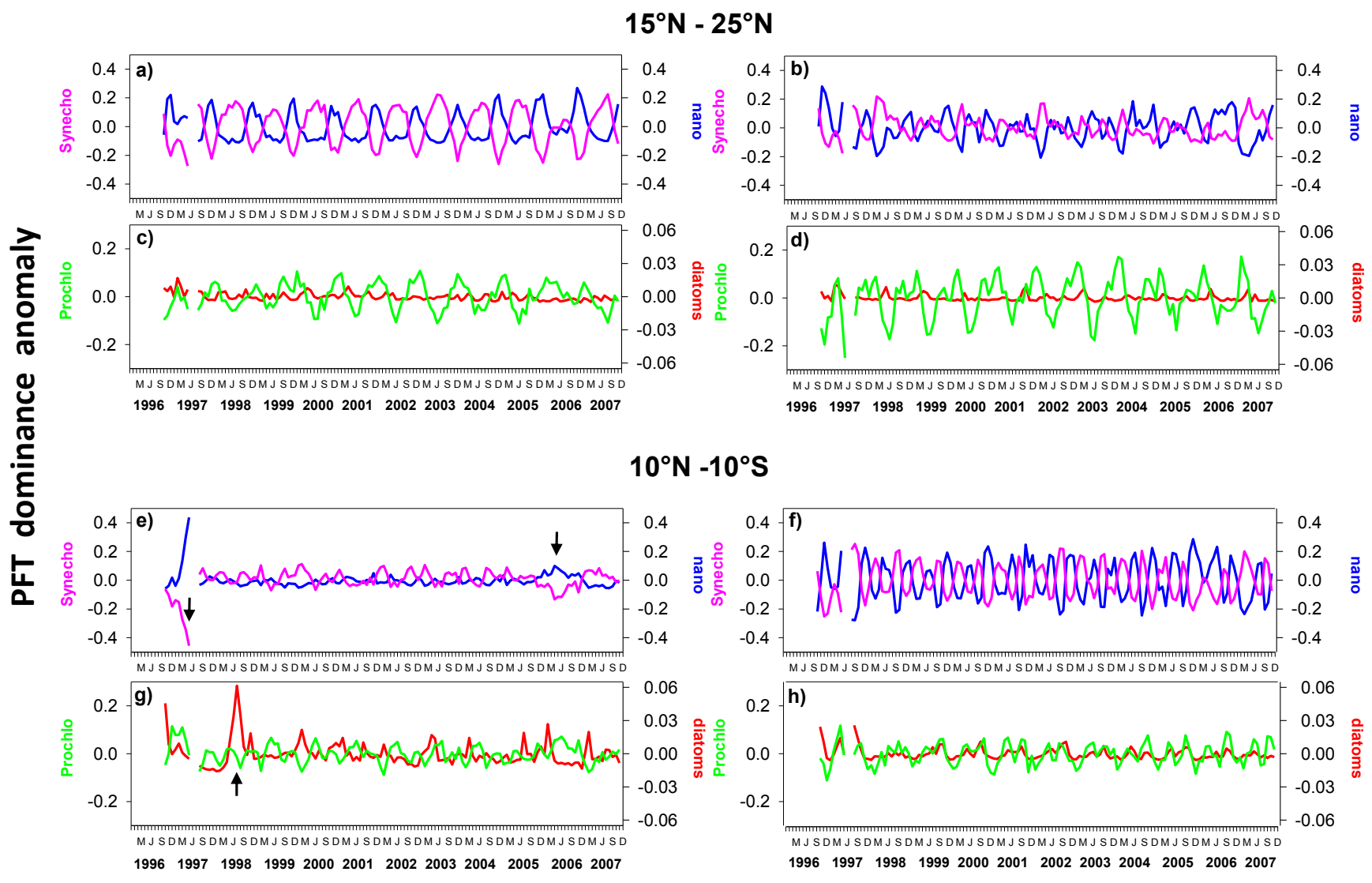

Fig. 5. The PFT dominance anomaly at tropical $\left(15^{\circ} \mathrm{N}-25^{\circ} \mathrm{N}\right)$ and equatorial $\left(10^{\circ} \mathrm{N}-10^{\circ} \mathrm{S}\right)$ latitudes in the Pacific and Atlantic Oceans (over 1996-2007) using the OCTS and SeaWiFS datasets. The PFT anomaly was generated from monthly maps of the relative frequency of the identified dominant phytoplankton group within each $1^{\circ} \times 1^{\circ}$ grid box. The longitudinal extent of the tropical regions was $180^{\circ} \mathrm{W}$ to $100^{\circ} \mathrm{W}, 80^{\circ} \mathrm{W}$ to $20^{\circ} \mathrm{W}$ for Pacific and Atlantic regions, respectively. The extent of the equatorial regions was $180^{\circ} \mathrm{W}$ to $80^{\circ} \mathrm{W}, 45^{\circ} \mathrm{W}$ to $11^{\circ} \mathrm{E}$ for Pacific and Atlantic regions, respectively. Arrows show the main maximum shift between Synechococcus and nanoeucaryotes during the early stages of El Niño (arrow in panel e) and for diatoms during La Niña (arrow in panel g).

with OCTS and SeaWiFS (Fig. 6). The decrease in Synechococcus and the increase in nanoeucaryote dominance is observed over the entire EQPAC region $\left(180^{\circ} \mathrm{W}-80^{\circ} \mathrm{W}\right.$, Fig. 6a and b) during both strong (May-June 1997) and the moderate (May-July 2006) El Niño events. A coincident decrease in Chl- $a$ concentrations is also observed during these two El Niño events (Fig. 6d), with mean values of $0.13 \mathrm{mg} \mathrm{m}^{-3}$ in May-June 1997 and $0.17 \mathrm{mg} \mathrm{m}^{-3}$ in MayJuly 2006 (the mean Chl- $a$ value in May-July for the whole 12 -yr period is $0.19 \mathrm{mg} \mathrm{m}^{-3}$, not including strong ENLN events). The decrease in phytoplankton biomass in this region during El Niño has already been noted (e.g., Strutton et al., 2008). However we show here that this decrease in biomass is associated with a decrease in the Synechococcus PFT and an increase in nanoeucaryote dominance. Furthermore, analyzing PFTs from PHYSAT in parallel to Chl- $a$ suggests that this nanoeucaryotic dominance during the early stages of El Niño is not due to increases in this PFT's abun- dance, but rather because Synechoccoccus almost disappears from surface waters due to unfavorable environmental conditions.

The increased dominance of diatoms observed during the La Niña event of 1998 covered almost the entire EQPAC region (Fig. 6c) and coincided with the highest mean Chl- $a$ value over 1996-2007 period (an average of $0.25 \mathrm{mg} \mathrm{m}^{-3}$ for the month of August 1998, Fig. 6d). On the contrary, we observe a disappearance of diatoms dominance in the eastern EQPAC region associated with the lower chlorophyll values typical of El Niño events (e.g. during 1997 and 2006 El Niño events). Similar to the PFT changes observed during El Niño events, it is likely that the increase in both the dominance of diatoms and Chl- $a$ are connected with changes in the environmental conditions during La Niña, such as changes to nutrient availability and sea-surface temperature that are directly controlled by ENLN events (Ryan et al., 2002; Pennington et al., 2006). Alternatively, diatoms are relatively 
a) nanoeucaryotes

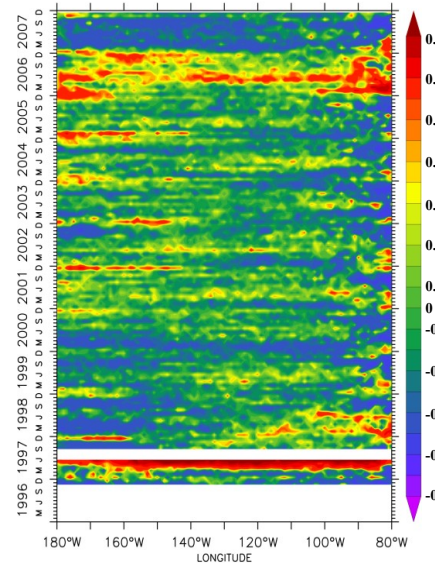

b) Synechococcus

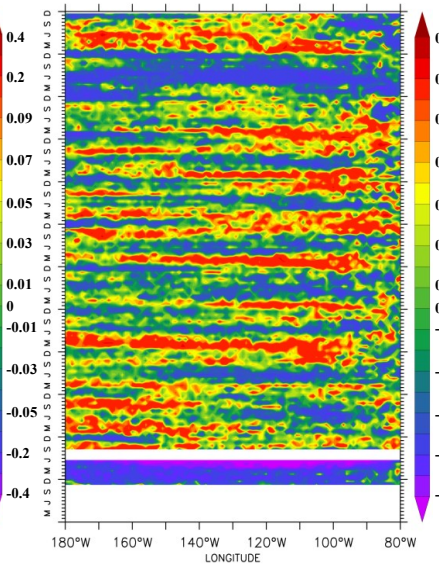

c) diatoms

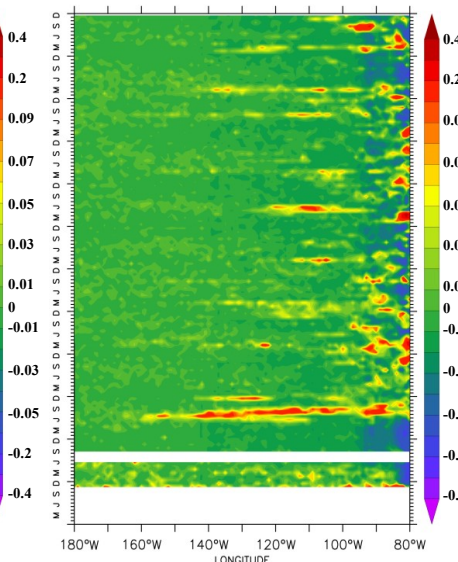

d) $\mathrm{Chl}-a\left(\mathrm{mg} \mathrm{m}^{-3}\right)$

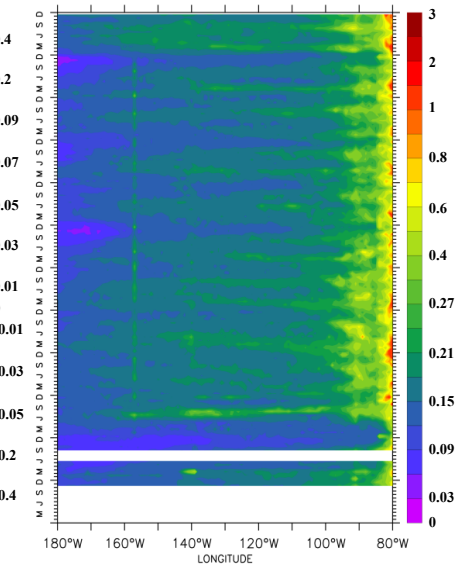

Fig. 6. Longitude-time plots of the (a) nanoeucaryotes, (b) Synechococcus, and (c) diatom dominance anomaly and (d) absolute satellite chlorophyll- $a$ (Chl- $a$ ) using OCTS-SeaWiFS datasets in the Equatorial Pacific region $\left(10^{\circ} \mathrm{N}-10^{\circ}\right.$ S) over 1996-2007. See Fig. 5 for details of PFT dominance anomaly.

dominant (even if 4-5 fold lower than the other groups) during strong to moderate la Niña events (1996, 1998, 2000 and 2005-2006, cf. Fig. 5g) when nutrients are more abundant. A detailed analysis of these increases in diatom dominance shows that this PFT exhibits a variable geographic distribution in the EQPAC region during La Niña events, including the recent 2007 event. For example, in our longitude-time plots of diatom dominance distributions (Fig. 6c), we find that diatoms merely dominated as small patches that did not extend westward of $140^{\circ} \mathrm{W}$ during the La Niña years, with no widespread dominance of the entire EQPAC region. The "patchy" nature of diatom dominance during La Niña events probably explains the lower integrated diatom dominance anomaly values over the entire EQPAC observed during these years (cf. Fig. 5g). On the other hand, widespread regional diatom blooms are observed in the early and strong La Niña of 1998 (August, Fig. 6c), whereas they are more scattered in the later and more moderate la Niña of 1996 (November).

\section{Discussion}

\subsection{Comparison with observations}

In situ observations during ENSO events show that surface $\mathrm{NO}_{3}$ is depleted during El Niño and enriched during La Niña; consequently, the phytoplankton community is dominated by picophytoplankton when El Niño conditions prevail and by diatoms when nutrients are high during La Niña (Chavez et al., 1999; Strutton and Chavez, 2000). In addition, our results for the EQPAC region $\left(180^{\circ} \mathrm{W}-80^{\circ} \mathrm{W}, 10^{\circ} \mathrm{N}-10^{\circ} \mathrm{S}\right)$ further suggest that a decrease in Synechococcus favors nanoeucaryote dominated waters during the early stage of El Niño (Figs. 5e, 6a and b). Nevertheless, after this initial period of change, the system is restored to the typical SynechococcusProchlorococcus dominance during the mature El Niño conditions (Fig. 5e).

Sparse field observations of phytoplankton community composition during ENLN transitions support our satellite based observations of shifts between Synechococcus and nanoeucaryote dominance. In situ observations from the western Equatorial Pacific suggest changes in the abundance of Synechococcus during ENLN transitions (Blanchot et al., 1992) that was manifested in a 4-fold reduction in the integrated abundance (to $120 \mathrm{~m}$ ) of "cyanobacteria" (essentially Synechococcus, J. Blanchot, personal communication, 2010) during El Niño (September 1987), relative to La Niña conditions (September 1988). Additionally, an earlier study along $165^{\circ} \mathrm{E}$ between $20^{\circ} \mathrm{S}$ and $7^{\circ} \mathrm{N}$ during weak conditions of the 1992 El Niño (August-September) also found Synechococcus to be a minor contributor $(<1 \%)$ to total phytoplankton biomass (Blanchot and Rodier, 1996). These observations are, to our knowledge, the only in situ evidence of reductions in Synechococcus dominance during El Niño events that can be used to support the evidence gleaned from PHYSAT.

Our PHYSAT analysis also shows that despite Synechococcus decreases during the early stages of the $1997 \mathrm{El}$ Niño (May-June, SOI $=-2.0$, cf. Fig. 2), there is a subsequent increase in Synechococcus dominance during the mature phase of the 1997 El Niño (September-November, SOI $=-3.0$ ). This agrees with Landry et al. (1996), who showed that Synechococcus was more numerous during the mature conditions of the 1992 El Niño (FebruaryMarch, SOI $=-3.5$ ) along the $140^{\circ} \mathrm{W}$ transect (at $12^{\circ} \mathrm{S}$ and $\left.12^{\circ} \mathrm{N}\right)$, than during the weak conditions of the $1992 \mathrm{El}$ Niño (August-September, SOI $=-0.4$ ). Finally, many studies have noted a reduction of diatom abundances during the 


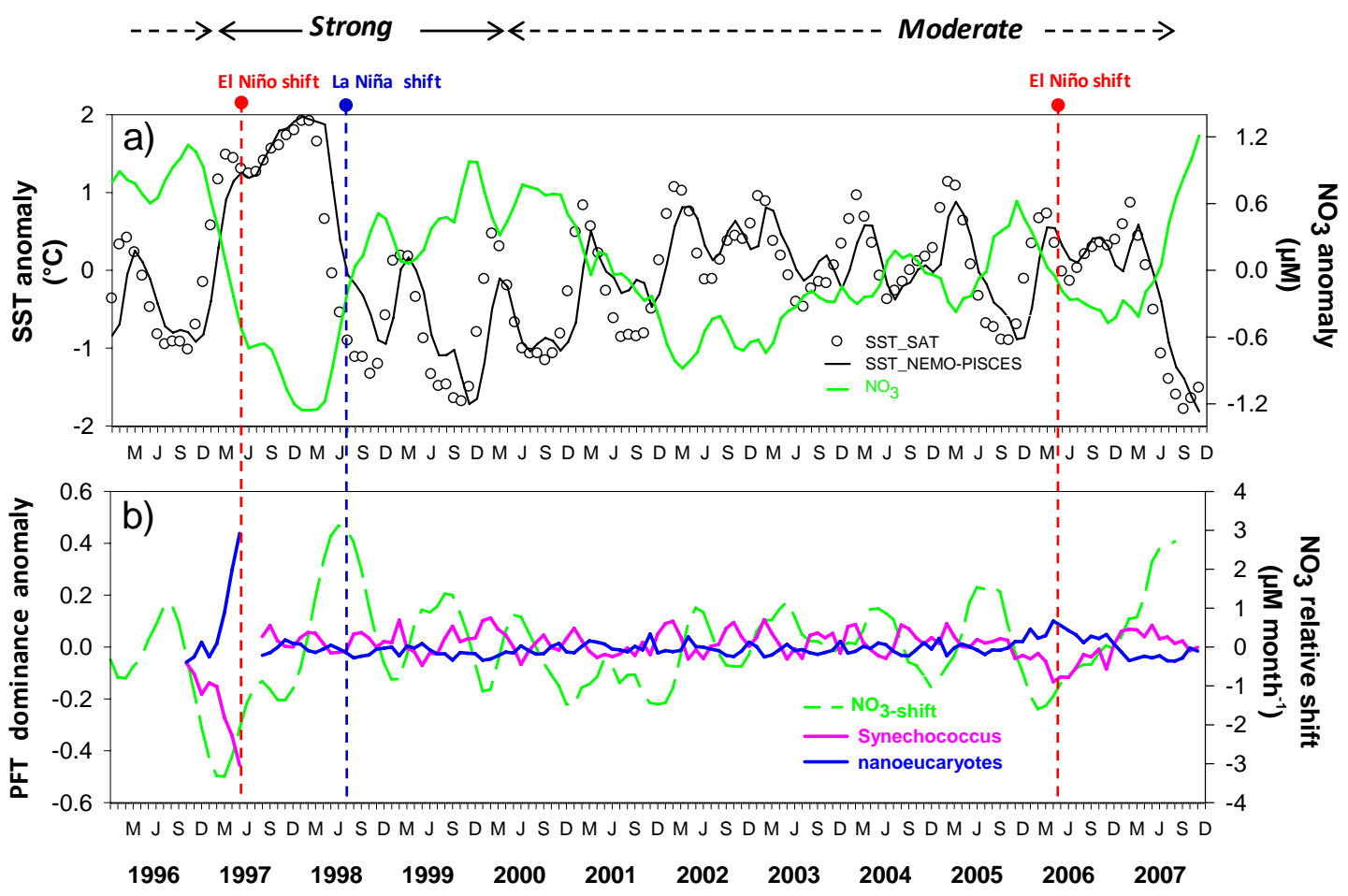

Fig. 7. The temporal evolution between 1996-2007 of the anomalies in (a) Sea-Surface-Temperature (SST) and nitrate (NO 3 ) and (b) Synechococcus and nanoeucaryotes. In addition, panel (b) also includes the relative shift in nitrate $\left(\mathrm{NO}_{3}\right.$-shift $)$ in the Equatorial Pacific region $\left(10^{\circ} \mathrm{N}-10^{\circ} \mathrm{S}, 180^{\circ} \mathrm{W}-80^{\circ} \mathrm{W}\right)$. The relative shift in nitrates $\left(\mathrm{NO}_{3}\right.$-shift $)$ in panel (b) corresponds to time derivative of surface $\mathrm{NO}_{3}$ concentrations obtained from the NEMO-PISCES model. The SST in panel a was obtained from either satellite (SST_SAT) or the NEMO-PISCES model (SST_NEMO-PISCES). Vertical dashed lines correspond to the onsets of El Niño (red) and La Niña (blue) periods associated to the main PFT shifts (cf. Fig. 5e and g).

mature phase of the 1992 El Niño, compared to non-El Niño conditions (Kaczmarska and Fryxell, 1995; Bidigare and Ondrusek, 1996; Liu et al., 1996; Latasa et al., 1997). Overall, the sparse field observations that exist generally support (i) a reduction in Synechococcus dominance during the onset of El Niño conditions, (ii) an increase in Synechococcus dominance during mature El Niño conditions and (iii) a reduction in diatom dominance during El Niño periods.

\subsection{Environmental control of PFT shifts}

In order to improve our understanding of this PFT shift observed in the EQPAC region, we examined the biogeochemical and physical conditions during strong and moderate ENLN events using the AVHRR sea surface temperature (SST) dataset and the NEMO-PISCES model simulation described previously (Sect. 2.2). Figure 7a shows that the SST from NEMO-PISCES and AVHRR observations are in good agreement, demonstrating that the atmospheric forcing and the ocean circulation from this model simulation properly accounts for ENLN events. Here, we used the simulated $\mathrm{NO}_{3}$ fields from NEMO-PISCES to better understand the links between the PFT dominance shifts observed with PHYSAT and the environmental conditions. We only used regional-mean $\mathrm{NO}_{3}$ in our analysis as $\mathrm{PO}_{4}$ and Fe concentrations show similar inter-annual variations (see: Sect. 2.2).

The rate of change in surface $\mathrm{NO}_{3}$ during ENLN transitions might be responsible for the decline in Synechococcus in the EQPAC region observed by PHYSAT. The time derivative (monthly) of $\mathrm{NO}_{3}$ obtained from the NEMOPISCES model between 1996-2007 ( $\mathrm{NO}_{3}$-shift, Fig. 7b) decreases abruptly during the two El Niño events ( -2.5 and $-0.9 \mu \mathrm{M}$ month $^{-1}$, for 1997 and 2006, respectively), exactly when PHYSAT suggests that Synechococcus dominance decrease. This suggests a direct relationship between Synechococcus dominance and $\mathrm{NO}_{3}$ availability. This result agrees with Partensky et al. (1999) who suggest that Synechococcus is much more abundant in nutrient-rich areas and that its distribution is generally restricted to the upper well-lit layer. The concomitant increase in Synechoccoccus and nitrogen availability $\left(\mathrm{NO}_{3}+\mathrm{NO}_{2}\right)$ observed along the equatorial Pacific transect between the warm pool $\left(165^{\circ} \mathrm{E}\right)$ and HNLC waters $\left(150^{\circ} \mathrm{W}\right)$ during the FLUPAC cruise (Partensky et al., 1999) further supports this link between Synechococcus and $\mathrm{NO}_{3}$. Additional evidence of this $\mathrm{NO}_{3}$-Synechococcus dependency in the EQPAC region 
was observed during the moderate El Niño conditions of October-December 2004, where Grob et al. (2007) show the highest abundance of Synechococcus (up to $10^{5}$ cells $\mathrm{ml}^{-1}$ ) under eutrophic conditions in the upwelling region $\left(\mathrm{NO}_{3} \sim\right.$ $5 \mu \mathrm{M}), 10$ and 20 fold more abundant than those detected in the mesotrophic subequatorial $\left(\mathrm{NO}_{3} \sim 1 \mu \mathrm{M}\right)$ and oligotrophic gyre $\left(\mathrm{NO}_{3} \sim 0.01 \mu \mathrm{M}\right)$ regions. This result agrees with the ranges of abundance of Synechococcus established in the literature for oligo-, meso- and eutrophic regions of the word's ocean, as suggested by a comparative review by Grob et al. (2007 and references therein).

A high $\mathrm{N}$ dependency of Synechococcus has also been observed in laboratory studies. For example, the Synechococcus half-saturation constant for ammonium uptake $(2.6 \mu \mathrm{MN})$ is 2.6 times higher than for other picophytoplankton species (Timmermans et al., 2005). Other laboratory studies suggest that Synechoccoccus utilizes a full range of $\mathrm{N}$ sources, including nitrate, nitrite, ammonium, urea and amino acids (Moore et al., 2002). As a result of its $\mathrm{N}$-rich phycobilisomes, Synechoccoccus also requires more N compared to Proclorococcus (Moore et al., 2002) and has a higher overall cellular $\mathrm{N}$ demand (Bertilsson et al., 2003; Heldal et al., 2003). On the other hand, Prochlorococcus has low cellular N requirements (Bertilsson et al., 2003; Heldal et al., 2003) and is extremely abundant in oligotrophic N-poor waters (Partensky et al., 1999). A higher requirement for $\mathrm{N}$ for Synechococcus, relative to other PFTs, would result in greater limitation of Synechococcus growth rates under the depleted $\mathrm{N}$ conditions that typify El Niño events. As such, ENLN changes in $\mathrm{NO}_{3}$ could drive the PFT shifts between El Niño and La Niña suggested by PHYSAT. By September 1997, the Synechococcus dominance anomaly returns to zero (Fig. 5e). At this time, although the $\mathrm{NO}_{3}$ concentration anomaly remains low (cf. Fig. 7a), the sign of the rela-

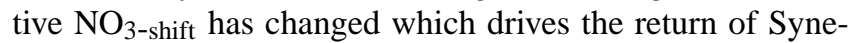
chococcus (Fig. 7b).

The large positive $\mathrm{NO}_{3}$ anomaly during the La Niña of 1998 coincides with the peak in diatom dominance (cf. Fig. 5g) that extends over much of the EQPAC region (Fig. 6c) and is associated with increased Chl- $a$. This peak in diatoms in August coincides with a largest positive shift in $\mathrm{NO}_{3}\left(3 \mu \mathrm{M}\right.$ month ${ }^{-1}$, cf. Fig. 7b) and the mean Chl- $a$ detected by satellite $\left(0.25 \mathrm{mg} \mathrm{m}^{-3}\right)$ in the EQPAC region over 1996-2007. We do not see an increase in Synechococcus dominance during this period, since diatoms are dominanting at high biomass. It could be possible that Synechococcus is increasing in this period, but it can not be detected by PHYSAT as diatoms dominate the signal. Observations concur with this overall increase in chlorophyll following the rapid temperature decrease during the strong la Niña of 1998 (Chavez et al., 1999; Ryan et al., 2002). As in August 1998, a weak diatom dominance peak was observed during moderate La Niña 1996 (Fig. 5g), but with a 3-fold lower value of Chl$a$ and relatively slow positive shift in $\mathrm{NO}_{3}$ (mean OctoberNovember $1996 \sim 0.2 \mu \mathrm{M}_{\text {month }^{-1}}$, Fig. $7 \mathrm{~b}$ ).
Our study has used distributions of the dominant PFT from satellite time series to propose that the onset of El Niño conditions could drive large changes in PFTs in the EQPAC. A subsequent analysis of the results, using an inter-annually forced global ocean biogeochemistry model, suggest that it is the rate of change in surface $\mathrm{NO}_{3}$ that drives these changes. However, despite the large scale changes in PFT at the onset of EL Niño, the community returns rapidly to its typical composition, even if Chl- $a$ is markedly lower (Figs. 5 and 6), which is indicative of adaptation by Synechococcus and a certain degree of resilience in community structure. While direct observations of in situ PFT during ENLN transitions are sparse, those that exist support our results. Nevertheless, we highlight the importance of PFT observations during ENLN alongside a measure of in situ changes in $\mathrm{NO}_{3}$ to further evaluate our hypothesis of the controlling mechanism. It is also possible that changes in the relative abundance of $\mathrm{NO}_{3}$ and $\mathrm{PO}_{4}$ between El Niño and La Niña (possibly driven by changes in subsurface denitrification and subsequent vertical supply) could be important since different phytoplankton groups can exhibit species-specific N:P requirements (Klausmeier et al., 2004). Other mechanisms controlling the PFT dominance shifts could be related to Fe availability in the EQPAC (e.g., Coale et al., 1996), and in particular for diatoms during the ENLN transition (Landry et al., 1997; Strutton et al., 2008). However, at this stage available in situ observations preclude a more detailed consideration of this issue.

\section{Summary and conclusions}

Biogeohemical and physical changes during ENSO cycles modify the phytoplankton community structure in the EQPAC region. We have used satellite ocean color observations from OCTS and SeaWiFS together with the PHYSAT algorithm (Alvain et al., 2005) to provide evidence for the large scale impact of ENLN events on the distribution of phytoplankton groups in the EQPAC. Specifically, the previously noted reduction in Chl- $a$ associated with the onset of El Niño conditions is associated with a shift in PFT dominance, from Synechococcus to nanoeucaryotes. The nutrient rich conditions that arise during La Niña events increase Chl- $a$, and promote diatom dominance of the phytoplankton community. Results of an interannually forced global model show that rapid and significant $\mathrm{NO}_{3}$ depletions drive the reduction in Synechococcus dominance during the onset of El Niño conditions. On the other hand, strong $\mathrm{NO}_{3}$ enrichment during the La Niña of 1998 favored the development of diatom blooms over large areas of the EQPAC, but this phenomenon was not observed with the same intensity during the other $\mathrm{La}$ Niña events of the period.

Our results also suggest that PFTs are relatively resilient to the strong environmental changes produced during El Niño events. The decrease in Synechococcus dominance took 
place only for a few months during the onset of El Niño events (e.g., May-July 2006) before returning to a typical phytoplankton composition, despite low overall biomass, which suggests that Synechococcus cells have the potential to adapt to low nutrient conditions. In the future, the shifts in PFT distribution and observed resilience of the phytoplankton community should be considered in modeling approaches in order to better understand the implications of such PFT shifts on the carbon cycle and the marine food-web in the EQPAC and beyond. Therefore, parallel satellite and modeling studies, alongside in situ PFT observations, will be necessary to improve our capability to model past shifts in PFTs and better understand those that might occur in the future.

\section{Supplementary material related to this article is available online at: http://www.biogeosciences.net/8/539/2011/ bg-8-539-2011-supplement.pdf.}

Acknowledgements. We thank the "Agence Nationale de la Recherche" (ANR, France) for the financial support for this work which was carried out within the framework of the "Globphy" project, and NASA/GSFC/DAAC for providing access to daily L3 OCTS and SeaWiFS binned products. We also thank NOAA-ESRL Physical Sciences Division, Boulder Colorado, for providing access to SST satellite products and Sauveur Belviso for his critical review of our manuscript. This work was performed using HPC resources from GENCI-IDRIS (Grant 2009-010040). This is LSCE contribution number 4487 .

Edited by: F. Chai

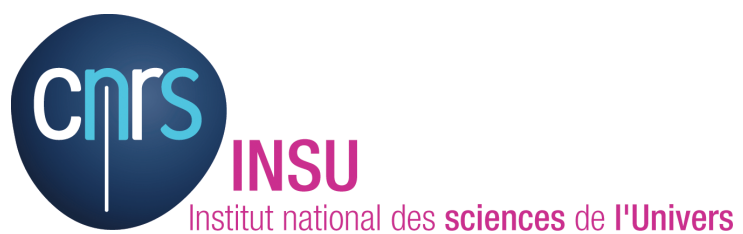

The publication of this article is financed by CNRS-INSU.

\section{References}

Alvain, S., Moulin, C., Dandonneau, Y., and Bréon, F. M.: Remote sensing of phytoplankton groups in case 1 waters from global SeaWiFS imagery, Deep-Sea Res. Pt. I, 52, 1989-2004, 2005.

Alvain, S., Moulin, C., Dandonneau, Y., and Loisel, H.: Seasonal distribution and succession of dominant phytoplankton groups in the global ocean: A satellite view, Global Biogeochem. Cy., 22, GB3001, doi:10.1029/2007GB003154, 2008.

Aumont, O. and Bopp, L.: Globalizing results from ocean in situ iron fertilization studies, Global Biogeochem. Cy., 20, GB2017, doi:10.1029/2005GB002591, 2006.

Behrenfeld, M. J. and Falkowski, P. G.: Photosynthetic rates derived from satellite-based chlorophyll concentration, Limnol. Oceanogr., 42, 1-20, 1997.
Behrenfeld, M. J., O’Malley, R. T., Siegel, D. A., McClain, C. R., Sarmiento, J. L., Feldman, G. C., Milligan, A. J., Falkowski, P. G., Letelier, R. M., and Boss, E. S.: Climate-driven trends in contemporary ocean productivity, Nature, 444, 752-755, 2006.

Bidigare, R. R. and Ondrusek, M. E.: Spatial and temporal variability of phytoplankton pigment distributions in the central equatorial Pacific Ocean, Deep-Sea Res. Pt. II, 43, 809-833, 1996.

Bertilsson, S., Berglund, O., Karl, D. M., and Chisholm, S. W.: Elemental composition of marine Prochlorococcus and Synechococcus: Implications for the ecological stoichiometry of the sea, Limnol. Oceanogr., 48, 1721-1731, 2003.

Blanchot, J. and Rodier, M.: Picophytoplankton abundance and biomass in the western tropical Pacific Ocean during the 1992 El Niño year: results from flow cytometry, Deep-Sea Res. Pt. I, 43, 877-895, 1996.

Blanchot, J., Rodier, M., and Le Bouteiller, A.: Effect of El Niño Southern Oscillation events on the distribution and abundance of phytoplankton in the western Pacific tropical ocean along $165^{\circ} \mathrm{E}$ J. Plankton Res., 14, 137-156, 1992.

Bopp, L., Monfray, P., Aumont, O., Dufresne, J. L., Le Treut, H. Madec, G., Terray, L., and Orr, J. C.: Potential impact of climate change on marine export production, Global Biogeochem. Cy., 15, 81-99, 2001.

Chavez, F. P., Strutton, P. G., Friederich, C. E., Feely, R. A., Feldman, G. C., Foley, D. C., and McPhaden, M. J.: Biological and chemical response of the equatorial Pacific Ocean to the 1997-98 El Niño, Science, 286, 2126-2131, 1999.

Coale, K. H., Johnson, K. S., Fitzwater, S. E., Gordon, R. M., Tanner, S., Chavez, F. P., Ferioli, L., Sakamoto, C., Rogers, P., Millero, F., Steinberg, P., Nightingale, P., Cooper, D., Cochlan, W. P., Landry, M. R., Constantinou, J., Rollwagen, G., Trasvina, A., and Kudela, R.: A massive phytoplankton bloom induced by an ecosystem-scale iron fertilization experiment in the equatorial Pacific Ocean, Nature, 383, 495-501, 1996.

Gorgues, T., Aumont, O., and Rodgers, K. B.: A mechanistic account of increasing seasonal variations in the rate of ocean uptake of anthropogenic carbon, Biogeosciences, 7, 2581-2589, doi:10.5194/bg-7-2581-2010, 2010.

Gregg, W. W. and Conkright, M. E.: Decadal changes in global ocean chlorophyll, Geophys. Res. Lett., 29(15), 1730, doi:10.1029/2002GL014689, 2002.

Grob, C., Ulloa, O., Claustre, H., Huot, Y., Alarcón, G., and Marie, D.: Contribution of picoplankton to the total particulate organic carbon concentration in the eastern South Pacific, Biogeosciences, 4, 837-852, doi:10.5194/bg-4-837-2007, 2007.

Heldal, M., Scanlan, D. J., Norland, S., Thingstad, F., and Mann, N. H.: Elemental composition of single cells of various strains of marine Prochlorococcus and Synechococcus using X-ray microanalysis, Limnol. Oceanogr., 48, 1732-1743, 2003.

Kaczmarska, I. and Fryxell, G. A.: Micro-phytoplankton of the Equatorial Pacific: $140^{\circ} \mathrm{W}$ meridianal transect during the 1992 El Niño, Deep-Sea Res., 42, 535-558, 1995.

Kalnay, E., Kanamitsun, M., Kistler, R., Collins, W., Deaven, D., Gandin, L., Iredell, M., Saha, S., White, G., Woollen, J., Zhu, Y., Chelliah, M., Ebisuzaki, W., Higgins, W., Janowiak, J., Mo, K. C., Ropelewski, C., Wang, J., Leetmaa, A., Reynolds, R., Jenne, R., and Joseph, D.: The NCEP/NCAR 40-year reanalysis project, B. Am. Meteorol. Soc., 77, 437-471, 1996.

Klausmeier, C. A., Litchman, E., Daufresne, T., and Levin, S. A.: 
Optimal N:P stoichiometry of phytoplankton, Nature, 429, 171174, 2004

Landry, M. R., Kirshtein, J., and Constantinou, J.: Abundances and distributions of picoplankton populations in the central equatorial Pacific from $12^{\circ} \mathrm{N}$ to $12^{\circ} \mathrm{S}, 140^{\circ} \mathrm{W}$, Deep-Sea Res. Pt. II, 43, 871-890, 1996.

Landry, M. R., Barber, R. T., Bidigare, R. R., Chai, F., Coale, K. H., Dam, H. G., Lewis, M. R., Lindley, S. T., McCarthy, J. J., Roman, M. R., Stoecker, D. K., Verity, P. G., and White, J. R.: Iron and grazing constraints on primary production in the central equatorial Pacific : an EqPac synthesis, Limnol. Oceanogr., 42, 405-418, 1997

Latasa, M., Landry, M. R., Schluter, L., and Bidigare, R. R.: Pigment-specific growth and grazing rates of phytoplankton in the central equatorial Pacific, Limnol. Oceanogr., 42, 289-298, 1997.

Liu, D., Greta, A., Fryxell, G. A., and Kaczmarska, I.: El Niño (1992) in the Equatorial Pacific: Low Biomass with a few dominating species in Micro-phytoplankton, J. Plankton Res., 18(7), 1167-1184, 1996.

Madec, G.: NEMO ocean engine, Note du Pole de modélisation, Institut Pierre-Simon Laplace (IPSL), France, No 27, ISSN-12881619, 2008

Moore, L. R., Post, A. F., Rocap, G., and Chisholm, S. W.: Utilization of different nitrogen sources by the marine cyanobacteria Prochlorococcus and Synechococcus, Limnol. Oceanogr., 47, 989-996, 2002

Partensky, F., Hess, W. R., and Vaulot, D.: Differential distribution of Prochlorococcus and Synechococcus in oceanic waters: a review, in: Marine Cyanobacteria, edited by: Charpy, L. and Karkum, A. W. D., Institut Oceanographique, Monaco, 457-475, 1999.

Pennington, J. T., Mahoney, K. L., Kuwahara, V. S., Kolber, D. D., Calienes, R., and Chavez, F. P.: Primary production in the eastern tropical Pacific: a review, Prog. Oceanogr., 69, 285-317, 2006.
Rodgers, K. B., Aumont, O., Menkes, C., and Gorgues, T.: Decadal variations in equatorial Pacific ecosystems and ferrocline/pycnocline decoupling, Global Biogeochem. Cy., 22, GB2019, doi:10.1029/2006GB002919, 2008.

Ryan, J. P., Polito, P. S., Strutton, P. G., and Chavez, F. P.: Unusual large-scale phytoplankton blooms in the equatorial Pacific, Prog. Oceanogr., 55, 263-285, 2002.

Sarthou, G., Timmermans, K. R., Blain, S., and Tréguer, P.: Growth physiology and fate of diatoms in the Ocean: a review, J. Sea, 53 , 25-42, 2005

Steinacher, M., Joos, F., Frölicher, T. L., Bopp, L., Cadule, P., Cocco, V., Doney, S. C., Gehlen, M., Lindsay, K., Moore, J. K., Schneider, B., and Segschneider, J.: Projected 21st century decrease in marine productivity: a multi-model analysis, Biogeosciences, 7, 979-1005, doi:10.5194/bg-7-979-2010, 2010.

Strutton, P. G. and Chavez, F. P.: Primary productivity in the equatorial Pacific during the 1997-1998 El Niño, J. Geophys. Res., 105, 26089-26101, 2000.

Strutton, P. G., Evans, W., and Chavez, F. P.: Equatorial Pacific chemical and biological variability, 1997-2003, Global Biogeochem. Cy., 22, GB2001, doi:10.1029/2007GB003045, 2008.

Timmermans, K. R., van der Wagt, B., Veldhuis, M. J. W., Maatman, A., and de Baar, H. J. W.: Physiological responses of three species of picophytoplankton to nitrogen, phosphorus, iron and light limitation, J. Sea Res., 53, 109-120, 2005.

Veldhuis, M. J. W. and Kraay, G. W.: Phytoplankton in the subtropical Atlantic Ocean: towards a better assessment of biomass and composition, Deep-Sea Res. Pt. I, 51(4), 507-530, 2004.

Veldhuis, M. J. W., Timmermans, K. R., Croot, P., and Van der Wagt, B.: Picophytoplankton; a comparative study of their biochemical composition and photosynthetic properties, J. Sea, 53, 7-24, 2005. 